\title{
The Influence of Cyclic Loading on Ultimate Bending Strength of Beech Solid and Laminated Wood
}

\section{Utjecaj cikličnog opterećenja na čvrstoću savijanja masivne i lamelirane bukovine}

\author{
Original scientific paper • Izvorni znanstveni rad \\ Received-prispjelo: 26. 6. 2013. \\ Accepted-prihvaćeno: 23. 6. 2014. \\ UDK: $630 * 812.71 ; 630 * .832 .286 ; 674.031 .632 .22$ \\ doi:10.5552/drind.2014.1336
}

\begin{abstract}
This work investigates the influence of cyclic loading of beech solid and laminated wood of various thicknesses on ultimate bending strength (ultimate flexural strength) $\sigma_{p}$ during bending in radial direction. For identification of ultimate bending strength, the static bending test with three-point loading was used. The ultimate bending strength was detected on testing samples that were not cyclically loaded and the results were compared with other results obtained from samples that were cyclically loaded. The results of this work show that the influence of cyclic loading on values of ultimate bending strength for solid and laminated wood is not significant. Thickness influence is a significant factor for both tested materials. The results show that the increase of thickness causes the decrease of ultimate bending strength. In our opinion, the decrease of ultimate bending strength is not caused by the sample thickness but by different sample lengths. With the increase of the sample length, the influence of inhomogeneous wood properties also increases.
\end{abstract}

Key words: cyclic loading, laminated wood, solid wood, ultimate bending strength, beech wood, PVAC adhesive

SAŽETAK・U radu se opisuje istraživanje utjecaja cikličnog opterećenja masivne i laminirane bukovine različitih debljina na graničnu čvrstoću savijanja (maksimalnu čvrstoću izvijanja) $\sigma_{p}$ tijekom savijanja u radijalnom smjeru. Za određivanje granične čvrstoće savijanja primijenjen je statički test savijanja s tri točke opterećenja. Granična čvrstoća savijanja određena je na uzorcima drva koji nisu bili ciklično opterećivani te je uspoređena s rezultatima dobivenima na uzorcima koji su bili ciklično opterećivani. Rezultati istraživanja pokazuju da utjecaj cikličnog opterećenja na vrijednosti granične čvrstoće savijanja za masivnu i lameliranu bukovinu nije statistički značajan. Debljina uzoraka imala je znatan utjecaj na graničnu čvrstoću savijanja u obje skupine uzoraka; rezultati pokazuju da se s povećanjem debljine smanjuje granična čvrstoća savijanja. Pretpostavlja se da smanjenje granične čvrstoće savijanja nije prouzročeno povećanjem debljine materijala već različitom duljinom uzoraka. S porastom duljine uzoraka povećava se i utjecaj nehomogenih svojstava drva.

Ključne riječi: ciklično opterećenje, lamelirano drvo, masivno drvo, granična čvrstoća savijanja, bukovina, PVAc ljepilo

\footnotetext{
${ }^{1}$ Author is assistant at Department of Furniture and Wood Products, Faculty of Wood Sciences and Technology, Technical University, Zvolen, Slovak Republic. ${ }^{2}$ Authors are assistant and professor at Department of Wood Processing, Faculty of Forestry and Wood Sciences, Czech University of Life Sciences, Prague, Czech Republic.

Autor je asistent Odjela za namještaj i drvne proizvode, Fakultet za znanost o drvu i drvnu tehnologiju, Tehničko sveučilište, Zvolen, Republika Slovačka. ${ }^{2}$ Autori su asistent i professor Odjela za preradu drva, Fakultet šumarstva i znanosti o drvu, Češko sveučilište bioloških znanosti, Prag, Republika Češka.
} 


\section{INTRODUCTION \\ 1. UVOD}

Lamination is the technology for producing a wood composite material - lamella. This technology is known mainly in the U.S., Canada and Scandinavian countries, but it is usually used in construction (Razumov et al., 2013) and not in the furniture industry. In Slovakia, the lamellae are mainly used for the production of some parts of beds.

Laminated veneer lumber is produced by combining thin wood veneers. Veneers are usually $3 \mathrm{~mm}$ thick and made by slicing (Barcík et al., 2011; Glos et al., 2004; Frese and Blaß, 2006). Direction of veneer fibers of laminated veneer lumber is parallel to the length of the finished products. The resulting product is characterized by improved mechanical properties and good dimensional stability compared to solid wood, which is why it is increasingly applied for the production of finished products for various purposes. Both hard and soft woods can be used for the production of laminated wood, depending on the needs of the customer. It is also possible to combine different types of wood according to their strength - e.g. outer layers of lamellae composed of softwood for aesthetic appearance and inner layers made from hardwood to achieve higher strength (Gáborík et al., 2001).

The aim of this research was to determine the effect of cyclic loading on strength properties of beech solid and laminated wood. Durability (lifetime) of these products varies considerably, affecting the properties of the material itself. As a result of long term use, the characteristics of furniture components change and over time cease to perform the function for which they were intended (Brutovský, 2013; Gaff, 2003; Gáborík and Dudas, 2006, 2008).

Our goal is to expand the knowledge related to certain products, which should largely determine the influence of monitored factors on the related characteristics and thus help to produce quality furniture products.

\section{MATERIALS AND METHODS}

2. MATERIJAL I METODE

The aim of this experiment was to determine the influence of cyclic loading on the ultimate bending strength $\sigma_{\mathrm{p}}$ of beech wood (Fagus sylvatica L.) - solid and laminated wood, when bending in the radial direction. The experiment investigated the changes of monitored characteristics that occurred after 0, 1000, 2000, 3000 cycles. For the purpose of detecting the influence of material thickness, tests were performed on samples made of $2 \mathrm{~mm}$ thick veneer glued together. The exact categorization of test pieces, for individual sets, is shown in Figure 1. The final dimensions of the test samples (after laminating) were $b=40 \mathrm{~mm}$ (width), $h$ $=4,6,10,18 \mathrm{~mm}$ (thickness), $l=(20 \cdot h) \mathrm{mm}$. The moisture content of test samples was $8 \%$. Laminated wood was glued by PVAC adhesive Duvilax D3 Rapid, with the following parameters:

- dry matter content: $49 \%$,

- viscosity: 4000 - $8000 \mathrm{~m} \mathrm{~Pa} \cdot \mathrm{s}$,

pH: 3-4,

- minimum film-forming temperature: $10{ }^{\circ} \mathrm{C}$,

- working time: 10 minutes,

- working temperature: $15-100{ }^{\circ} \mathrm{C}$,

- drying time at $20^{\circ} \mathrm{C}: 10-30$ minutes,

- wood moisture content: 8-12\%.

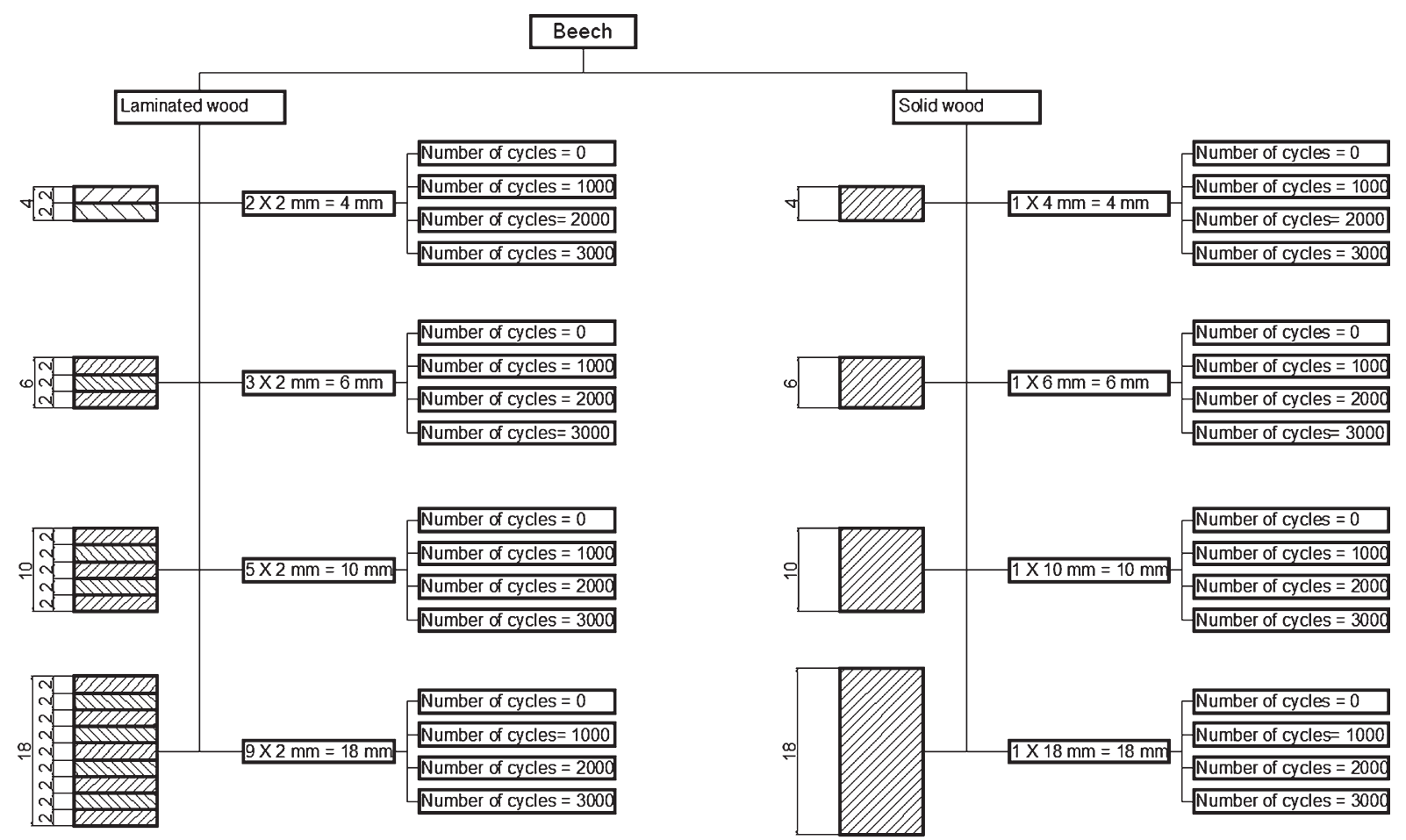

Figure 1 Categorization of testing sample sets

Slika 1. Kategorizacija uzoraka za provedbu istraživanja 


\subsection{Determination of ultimate bending strength}

2.1. Određivanje granične čvrstoće savijanja

The varying thickness of test samples had to comply with the condition, which provides a span of $20 \cdot h$. Loading rate was set so that the breaking of the test sample occurred during the $1.5 \pm 0.5 \mathrm{~min}$ from the start of loading. Flexure was measured at the center of the test sample under bending pin to the accuracy of $0.1 \mathrm{~mm}$, and the measured value was recorded together with the corresponding loading measured to the accuracy of $1 \%$ of the measured values (Fig. 2). Loading break was recorded to the accuracy of $1 \%$ of the measured value.

The ultimate bending strength, at three-point bending, was calculated according to Equation 1 from STN 490115 and Gáborík et al. (2011):

$$
\sigma=E \cdot \varepsilon=\frac{3 \cdot F \cdot l_{0}}{2 \cdot b \cdot h}
$$

Where:

$\sigma$ - ultimate bending strength, $\mathrm{MPa}$,

$F-$ load (force) at fracture point, N,

$l_{0}$ - axial length of support span $\left(l_{0}=20 \cdot h\right), \mathrm{mm}$,

$b$ - test sample width, mm,

$h$ - test sample thickness, mm,

$E$ - modulus of elasticity (flexural modulus), $\mathrm{MPa}$,

$\varepsilon$ - relative strain (deformation).

Measured and calculated values are converted to ultimate bending strength at $12 \%$ moisture content rounded to $1 \mathrm{MPa}$ according to STN 490115 and Equation 2:

$$
\sigma_{12}=\sigma_{w} \cdot[1+\alpha \cdot(w-12)]
$$

Where:

$\sigma_{12}$ - ultimate bending strength of wood at $12 \%$ moisture content, $\mathrm{MPa}$,

$\sigma_{w}$ - ultimate bending strength of wood at a certain moisture content, $\mathrm{MPa}$,

$w$ - moisture content of the test sample during testing, $\%$,

$\alpha$-moisture correction factor, which is 0.04 for all wood species.

\subsection{Cyclic loading by bending}

\subsection{Ciklično opterećenje na savijanje}

Cyclic loading of samples was performed by a cycler machine (Fig. 3), which is based on the principle of cyclic bending of test samples by uniaxial (unilateral) loading. The number of cycles was 0, 1000, 2000 and 3000 . In preliminary tests, test samples were loaded by static bending in order to detect ultimate strength and proportionality limit, because the test samples were to be loaded to $90 \%$ of proportionality limit

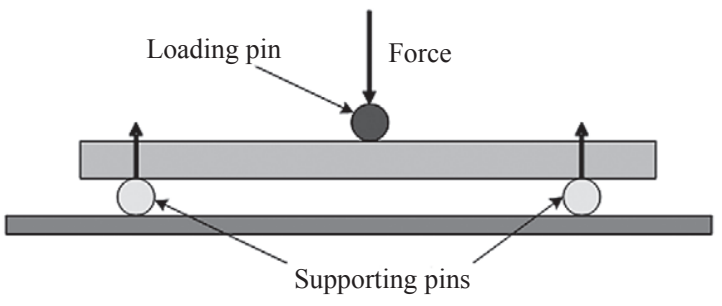

Figure 2 Basic principle of three point bending test Slika 2. Osnovno načelo testa savijanja s tri točke

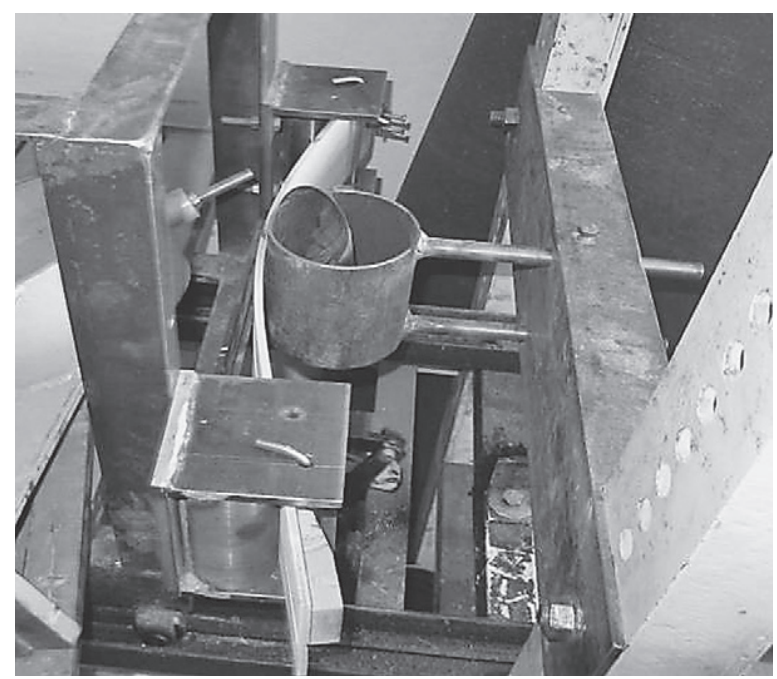

Figure 3 Cycler machine

Slika 3. Uređaj za ciklično opterećenje

(Maro, 2012; Brutovský, 2013). 90 \% proportionality limit was chosen so as not to exceed the value due to the diversity of material properties. This action will ensure that all test samples will be loaded so that the limit of elastic area is not exceeded.

\section{RESULTS AND DISCUSSION}

\section{REZULTATI I RASPRAVA}

\subsection{Laminated wood}

3.1. Lamelirano drvo

Table 1 shows the results of variance analysis that evaluates the influence of the material thickness, number of cycles and their mutual interaction. According to these results, it can be concluded that the influence of cyclic loading has no significant effect on the values of ultimate bending strength for laminated beech wood (Fig. 4).

Table 1 also shows that the second test factormaterial thickness, has a significant influence on the values of the tested characteristics. Mutual interaction, between the number of cycles and material thickness, also has a significant effect.

However, the influence of the test factor, number of loading cycles, on the values of ultimate bending strength can be considered as insignificant (Fig. 4).

If material thickness increases, then the values of ultimate bending strength go down (Fig. 5). Statistically the most significant difference occurs at material thicknesses of $6 \mathrm{~mm}, 10 \mathrm{~mm}$ and $18 \mathrm{~mm}$.

Basically the variance analysis that evaluates the influence of interaction between the two factors - material thickness and number of cycles on ultimate bending strength (Tab. 1), shows that statistically the effect of this interaction of factors is moderately significant (Fig. 6).

Graphs of $95 \%$ confidence intervals represent the influence of material thickness and number of cycles on ultimate bending strength during bending of laminated wood (Fig. 6) and show that the influence was proved because of expressive effect of various material thicknesses. 


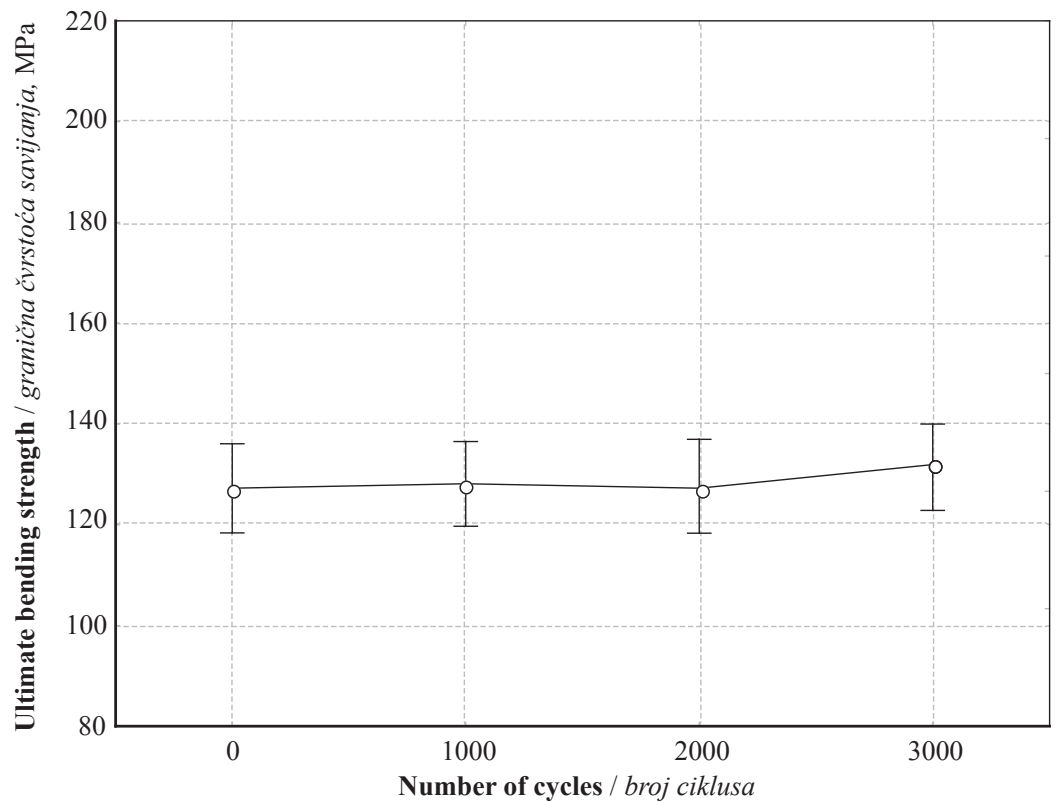

Figure 4 Influence of number of cycles on ultimate bending strength during bending of laminated wood Slika 4. Utjecaj broja ciklusa opterećenja na graničnu čvrstoću savijanja uzoraka od lamelirane bukovine

Table 1 Basic table of two-factor analysis of variance that evaluates the influence of individual factors on the change of ultimate bending strength values of laminated wood

Tablica 1. Osnovna tablica analize varijance za ocjenu utjecaja pojedinačnih činitelja na graničnu čvrstoću savijanja lameliranog drva

\begin{tabular}{|l|c|c|c|c|c|}
\hline \multicolumn{1}{|c|}{$\begin{array}{c}\text { Monitored factor } \\
\text { Promatrani činitelj }\end{array}$} & $\begin{array}{c}\text { Sum of } \\
\text { squares } \\
\text { Zbroj kvadrata }\end{array}$ & $\begin{array}{c}\text { Degrees of } \\
\text { freedom } \\
\text { Stupanj slobode }\end{array}$ & $\begin{array}{c}\text { Variance } \\
\text { Varijanca }\end{array}$ & $\begin{array}{c}\text { Fisher's } \\
\text { F- Test } \\
\text { Fišerov F-test }\end{array}$ & $\begin{array}{c}\text { Significance level P } \\
\text { razina signifikantnosti P }\end{array}$ \\
\hline Absolute term / apsolutni razmak & $2,647,947$ & 1 & $2,647,947$ & $17,583.79$ & 0.000000 \\
\hline Number of cycles / broj ciklusa & 594 & 3 & 198 & 1.31 & 0.271996 \\
\hline $\begin{array}{l}\text { Material thickness } \\
\text { debljina materijala }\end{array}$ & 69,112 & 3 & 23,037 & 152.98 & 0.000000 \\
\hline $\begin{array}{l}\text { Number of cycles * Material } \\
\text { thickness / broj ciklusa * debljina } \\
\text { materijala }\end{array}$ & 4,424 & 9 & 492 & 3.26 & 0.001215 \\
\hline Error / pogreška & 21,685 & 144 & 151 & & \\
\hline
\end{tabular}

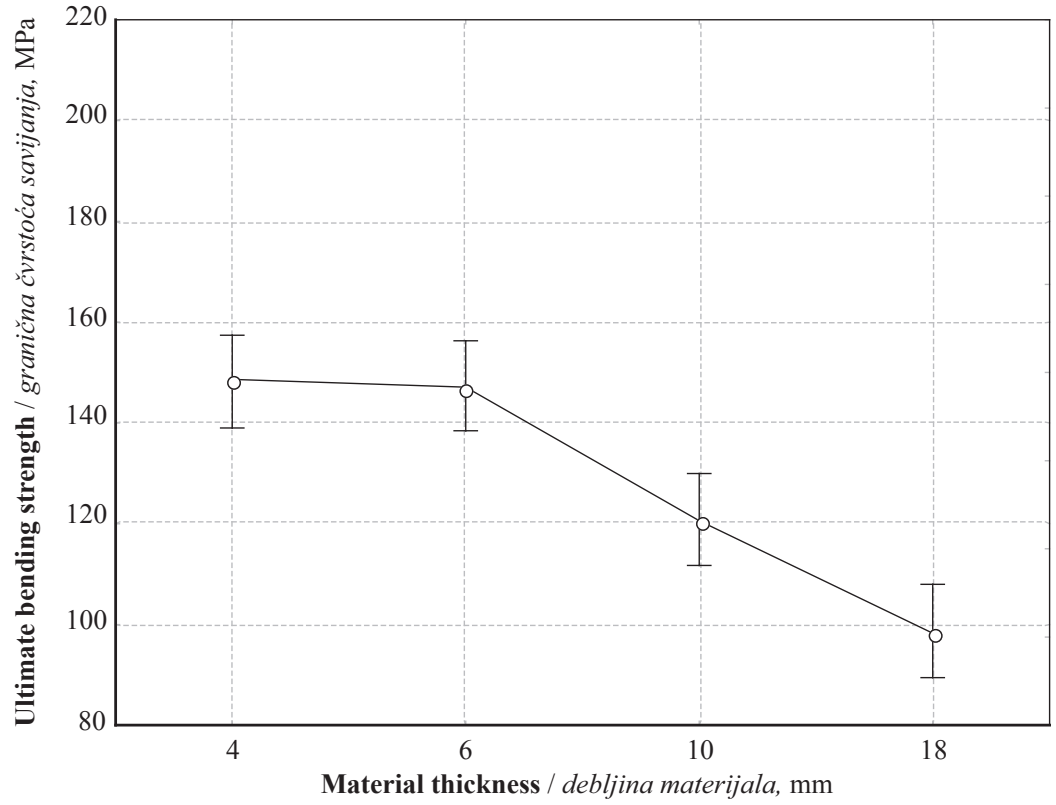

Figure 5 Influence of material thickness on ultimate bending strength during bending of laminated wood Slika 5. Utjecaj debljine materijala na graničnu čvrstoću savijanja uzoraka od lamelirane bukovine 


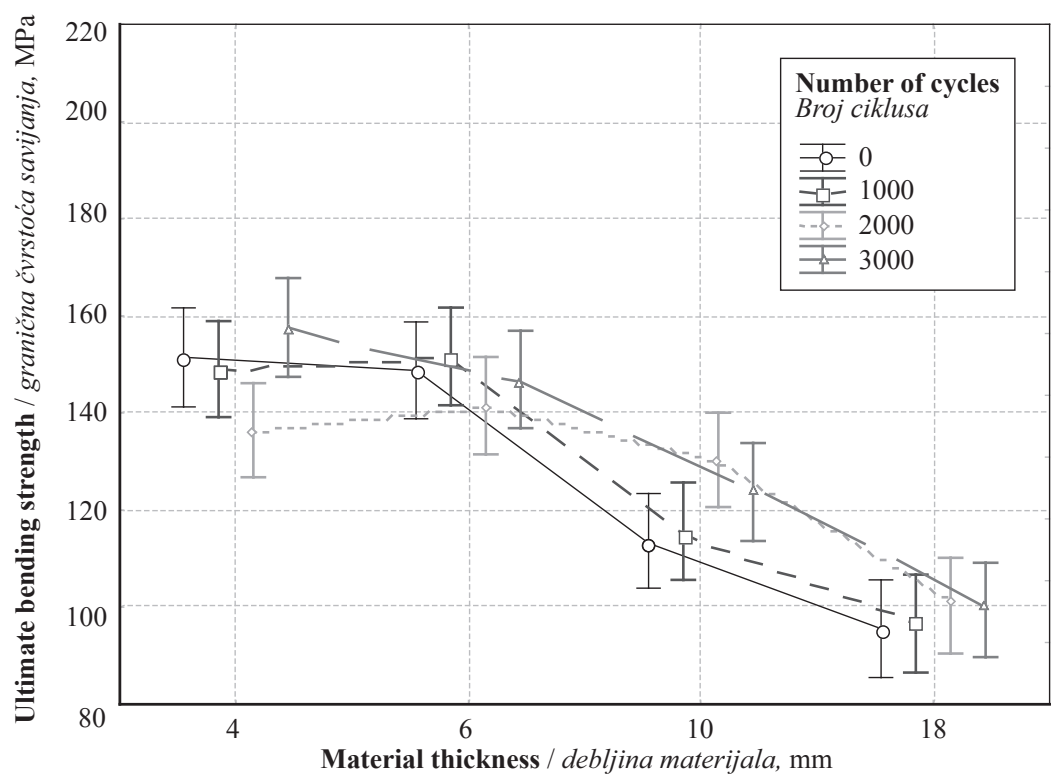

Figure 6 Influence of material thickness and number of cycles on ultimate bending strength during bending of laminated wood

Slika 6. Utjecaj debljine materijala i broja ciklusa opterećenja na graničnu čvrstoću savijanja uzoraka od lamelirane bukovine

\subsection{Solid wood}

\subsection{Masivno drvo}

When evaluating the influence of test factors on ultimate bending strength of solid wood (Tab. 2), the same results were obtained as for laminated wood (Tab.1). The influence of the number of cycles was statistically insignificant, while the influence of material thickness was statistically significant in affecting the values of ultimate bending strength of solid wood.

Statistically, the interaction between the test factors was moderately significant, similarly as with laminated wood. Statistically insignificant influence of the number of cycles on ultimate bending strength is also proved by the results shown in Figure 7.
The values of ultimate bending strength decrease with the increase of thickness of solid wood as shown in Figure 8. This figure also proves that the lowest values of ultimate bending strength were measured at 18 $\mathrm{mm}$ material thickness.

The graph of confidence intervals represents the influence of the number of cycles and material thickness on ultimate bending strength during bending of solid wood (Fig. 9). This graph shows that with the increase of material thickness, the values of ultimate bending strength go down. The number of cycles has no statistically significant effect on values of ultimate bending strength.

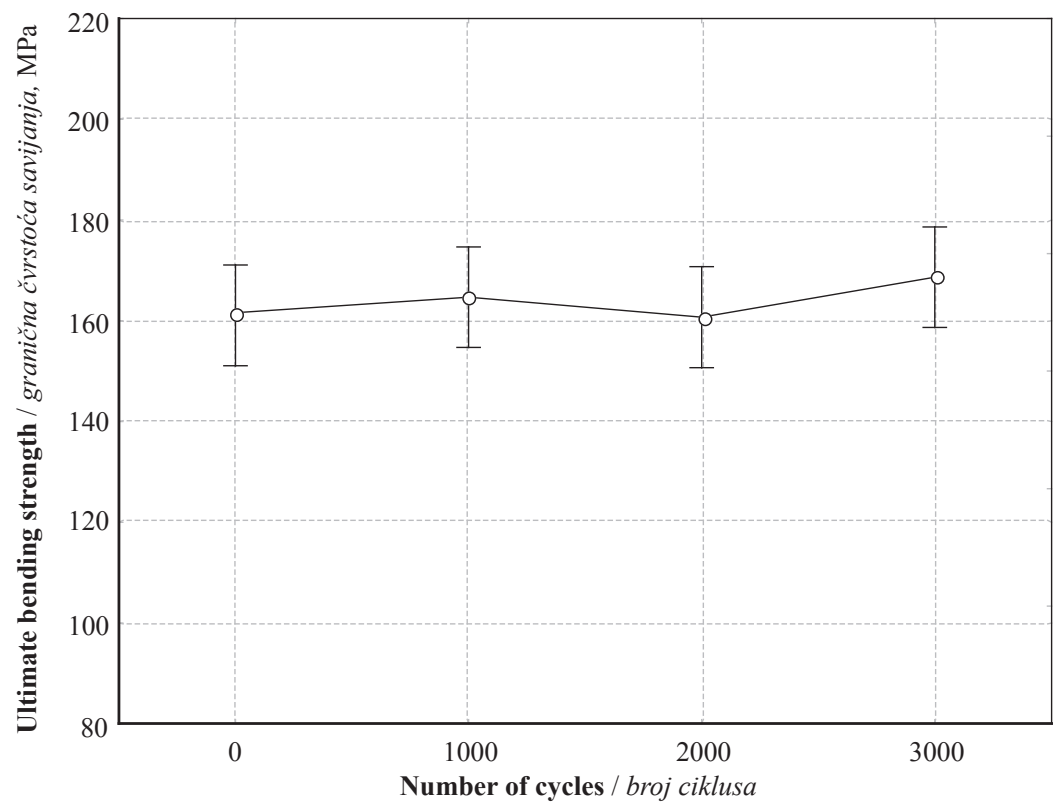

Figure 7 Influence of number of cycles on ultimate bending strength during bending of solid wood Slika 7. Utjecaj broja ciklusa opterećenja na graničnu čvrstoću savijanja uzoraka od masivne bukovine 


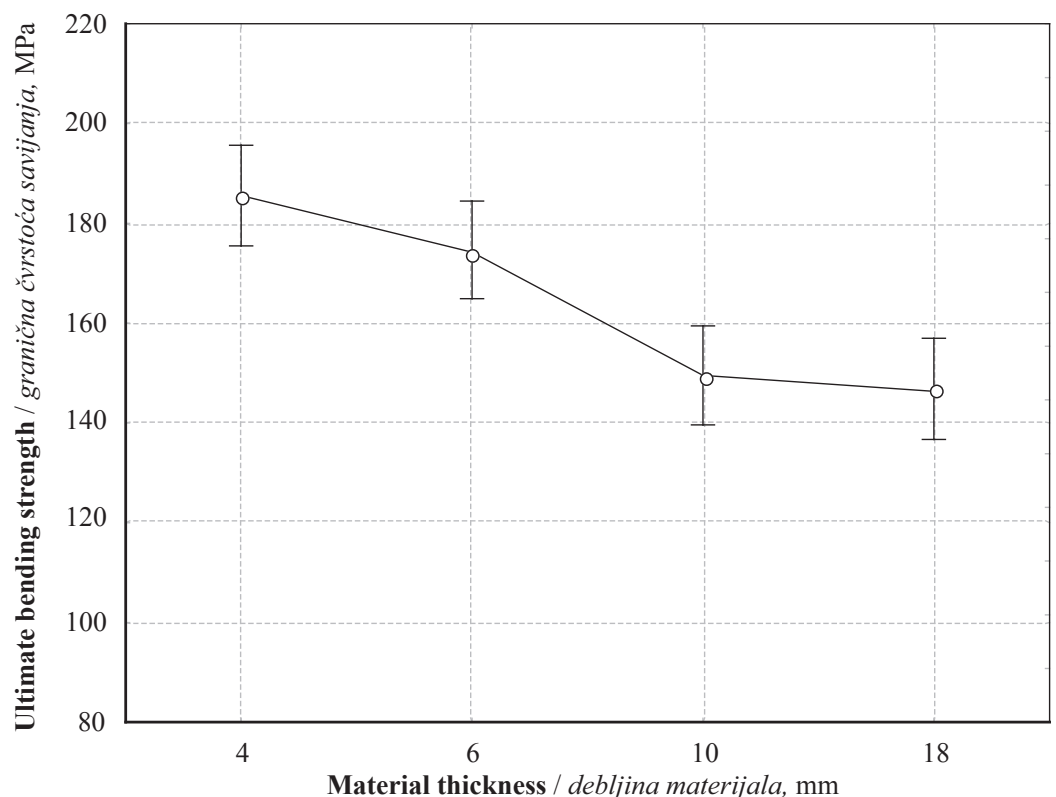

Figure 8 Influence of material thickness on ultimate bending strength during bending of solid wood Slika 8. Utjecaj debljine materijala na graničnu čvrstoću savijanja uzoraka od masivne bukovine

Table 2 Basic table of two-factor analysis of variance that evaluates the influence of individual factors on change of ultimate bending strength of solid wood

Tablica 2. Osnovna tablica analize varijance za ocjenu utjecaja pojedinačnih činitelja na graničnu čvrstoću savijanja masivne bukovine

\begin{tabular}{|l|c|c|c|c|c|}
\hline \multicolumn{1}{|c|}{$\begin{array}{c}\text { Monitored factor } \\
\text { Promatrani činitelj }\end{array}$} & $\begin{array}{c}\text { Sum of } \\
\text { squares } \\
\text { Zbroj } \\
\text { kvadrata }\end{array}$ & $\begin{array}{c}\text { Degrees of } \\
\text { freedom } \\
\text { Stupanj } \\
\text { slobode }\end{array}$ & $\begin{array}{c}\text { Variance } \\
\text { Varijanca }\end{array}$ & $\begin{array}{c}\text { Fisher's } \\
\text { F- Test } \\
\text { Fišerov F-test }\end{array}$ & $\begin{array}{c}\text { Significance } \\
\text { level P } \\
\text { razina signifikant- } \\
\text { nosti P }\end{array}$ \\
\hline Absolute term / apsolutni razmak & $4,298,682$ & 1 & $4,298,682$ & $16,011.79$ & 0.000000 \\
\hline Number of cycles / broj ciklusa & 1,548 & 3 & 516 & 1.92 & 0.128635 \\
\hline Material thickness / debljina materijala & 43,619 & 3 & 14,540 & 54.16 & 0.000000 \\
\hline $\begin{array}{l}\text { Number of cycles * Material thickness } \\
\text { broj ciklusa * debljina materijala }\end{array}$ & 7,303 & 9 & 811 & 3.02 & 0.002456 \\
\hline Error / pogreška & 38,660 & 144 & 268 & & \\
\hline
\end{tabular}

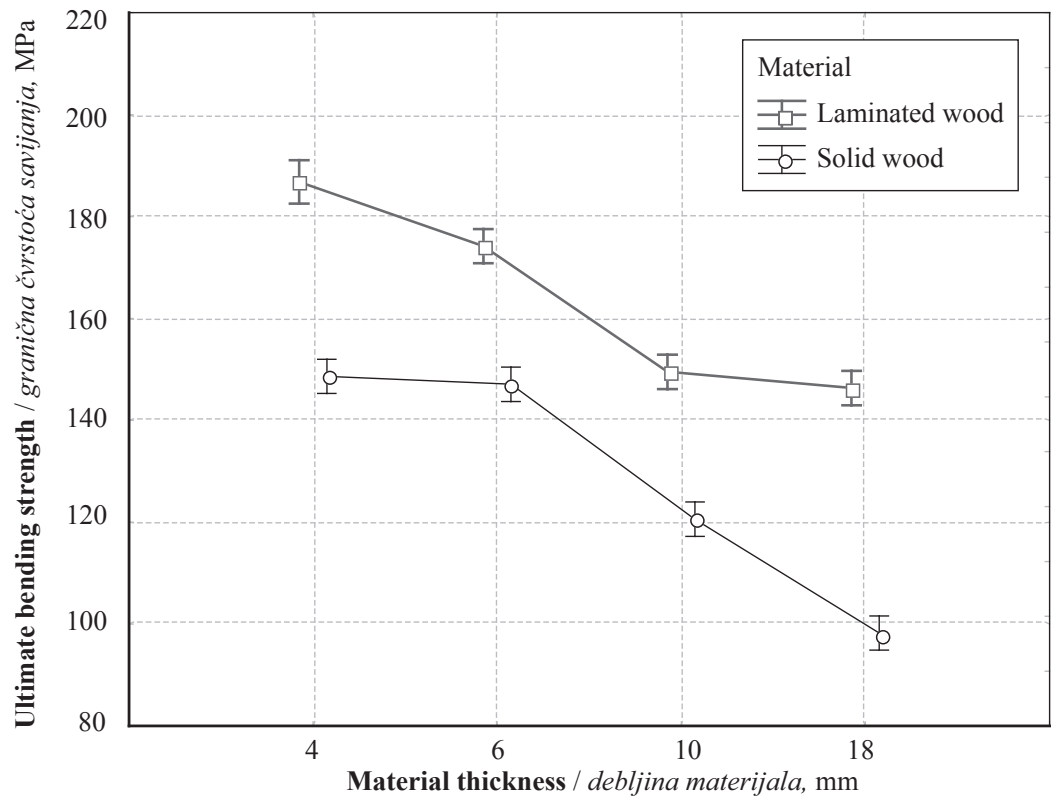

Figure 9 Influence of material thickness on ultimate bending strength during bending of laminated wood and solid wood Slika 9. Utjecaj debljine materijala na graničnu čvrstoću savijanja uzoraka od lamelirane i masivne bukovine 
Generally, laminated wood showed the lowest values of ultimate bending strength (Fig. 9).

Measurements prove that solid wood has about $30 \mathrm{MPa}$ higher values of ultimate bending strength than laminated wood. These results (ultimate bending strength goes down with increasing material thickness) also correspond to the results of Stark (1997), who found out that if conditions of slenderness ratio $(20 \mathrm{x}$ material thickness) are kept at a level, the values of ultimate bending strength goes down because of increasing of material length. In fact, heterogeneous distribution of properties is higher with the increase of material length.

Other possibilities of modification of these materials should be sought aimed at improving the properties of furniture.

\section{CONCLUSIONS \\ 4. ZAKLJUČAK}

Based on the results of this study, the following conclusions and recommendations can be made:

- number of loading cycles has no significant effect on values of ultimate bending strength with either test material (solid and laminated wood),

- material thickness has a strong influence. With the increase of material thickness, the values of ultimate bending strength of both types of material go down significantly,

- the interaction of material thickness and number of cycles affects the values of ultimate bending strength. However, Figure 5, 6, 9 and 10 show that this influence is caused by material thickness,

- generally, when comparing individual results, it can be stated that the values of ultimate bending strength of laminated wood are on average about 30 $\mathrm{MPa}$ lower.

\section{Acknowledgments - Zahvala}

The authors are grateful for the support of VEGA grant No. 1/0581/12 and also for the support from CIGA (CULS Grant Agency) project No. 20124311.

\section{REFERENCES}

\section{LITERATURA}

1. Barcík, Š.; Kvietková, M.; Aláč, P., 2011: Effect of the chosen parameters on deflection angle between cutting sides during the cutiing of aglomerated materials by water jet. Wood Research, 56 (4): 577-588.
2. Brutovský, T., 2013: Pružnostné vlastnosti lamelového materílov na báze dreva a nedrevených komponentov. Technical University in Zvolen, 95 p. Master's Thesis.

3. Frese, M.; Blaß, H. J., 2006: Characteristic bending strength of beech glulam. Materials and structures 40: 3-13. http://dx.doi.org/10.1617/s11527-006-9117-9

4. Gaff, M., 2003: Tvárnenie dreva osiky lisovaním s využitím vysokofrekvenčnej energie. Technical University in Zvolen. 105 p. Master's Thesis.

5. Gáborík, J.; Dudas, J., 2006: The change of properties of aspen wood by mechanical treatment - by pressing. Electronic Journal of Polish Agricultural Universities 9 (3).

6. Gáborík, J.; Dudas, J., 2008: The bending properties of aspen wood. Annals of Warsaw Agricultural University of Life Sciences. Forestry and Wood Technology, 65: 5560.

7. Gáborík, J.; Joščák, P.; Kulík, J.; Grznárik, T., 2011: Properties of compressed laminated beech wood by bending stress. Annals of Warsaw Agricultural University of Life Sciences. Forestry and Wood Technology, 74: 63-68.

8. Glos, P.; Denzler, J. K.; Linsenmann, P., 2004: Strength and stiffness behaviour of beech laminations for high strength glulam. Proceeding Meeting 37 CIB Working Commission W18-Timber Structures, paper CIBW18/37-6-3, Edingburgh, UK.

9. Maro, M., 2012: Vlastnosti lamelového dreva na báze dýhových lisovaných komponentov. Technical University in Zvolen, 100 p. Master's Thesis.

10. Razumov, E.; Safin, R.; Barcík, Š.; Kvietková, M.; Khasanshin, R., 2013: Studies on mechanical properties of composite materials based on thermo modified timber. Drvna Industrija, 64 (1): 3-8. http://dx.doi.org/10.5552/drind.2013.1206

11. Stark, N., 1997: Effect of Species and Particle Size on Properties of Wood-Flour-Filled Polypropylene Composites. In: Functional Fillers for Thermoplastics and Termosets. Le Meridien at Coronado, San Diego, California, USA, $22 \mathrm{p}$.

12. STN 490115:1979. Wood. Determination of ultimate strength in flexure tests. Slovak Standards Institute.

\section{Corresponding address:}

Assistant Ing. MIROSLAV GAŠPARÍK, Ph.D.

Czech University of Life Sciences Prague

Faculty of Forestry and Wood Sciences

Department of Wood Processing

Kamýcká 129

16521 Praha 6 - Suchdol, CZECH REBUBLIC

e-mail: gathiss@gmail.com 